\title{
Syntheses of immunomodulating androstanes and stigmastanes: Comparison of their TNF- $\alpha$ inhibitory activity
}

\author{
Javier A. Ramírez, ${ }^{\mathrm{a}, *}$ Andrea C. Bruttomesso, ${ }^{\mathrm{a}}$ Flavia M. Michelini, ${ }^{\mathrm{b}}$ Sofía L. Acebedo, \\ Laura E. Alchéb and Lydia R. Galagovsky ${ }^{\mathrm{a}}$ \\ a Departamento de Química Orgánica and UMYMFOR (CONICET_Facultad de Ciencias Exactas y Naturales), \\ Universidad de Buenos Aires, Pabellón 2, Piso 3, Ciudad Universitaria, C1428EGA, Buenos Aires, Argentina \\ ${ }^{\mathrm{b}}$ Laboratorio de Virología: Agentes Antivirales y Citoprotectores, Departamento de Química Biológica, \\ Facultad de Ciencias Exactas y Naturales, Universidad de Buenos Aires, Pabellón 2, Piso 4, \\ Ciudad Universitaria, C1428EGA, Buenos Aires, Argentina
}

Received 6 July 2007; revised 10 September 2007; accepted 10 September 2007 Available online 14 September 2007

\begin{abstract}
In a previous work our group showed that some synthetic stigmastanes may play a role in immune-mediated inflammation. In this paper we report the syntheses of a series of new steroidal compounds derived from dehydroepiandrosterone and stigmasterol, and the evaluation of their in vitro inhibitory activity of the TNF- $\alpha$ production by macrophages. A preliminary qualitative structure-activity relationship was established.

(c) 2007 Elsevier Ltd. All rights reserved.
\end{abstract}

\section{Introduction}

Inflammation is a tightly regulated normal physiological process triggered in response to cellular injury or infection. An acute inflammatory reaction consists of a diverse population of leukocytes infiltrating to the site of injury or infection. The cellular infiltrate typically consists of immune cells including neutrophils, macrophages, and dendritic cells. This diverse cell population is responsible for the production of cytokines and cellular factors that directly or indirectly orchestrate a number of important cellular processes that eventually lead to repair and healing in physiological conditions. ${ }^{1}$

Tumor necrosis factor $\alpha$ (TNF- $\alpha)$ is a key cytokine produced primarily by monocytes and macrophages which is involved in the host immune response. During normal host defense, low levels of serum TNF- $\alpha$ confer protection against infectious agents, tumors, and tissue damage, and have an important role in the development of the humoral immune response. On the other hand,

Keywords: Steroids; DHEA; Androstane; Stigmastane; Tumor necrosis factor- $\alpha$; Immune regulation.

* Corresponding author. Tel.: +54 01145763346; fax: +54 01145763385.; e-mail: jar@qo.fcen.uba.ar
TNF- $\alpha$ can contribute to the pathogenesis of both infectious and autoimmune diseases. ${ }^{2}$

Dehydroepiandrosterone (DHEA, 1, Fig. 1), the most abundant steroid in human circulating blood, has been shown to inhibit proinflammatory cytokines such as interleukin-6 (IL-6) and TNF- $\alpha,{ }^{3,4}$ suggesting an important role for DHEA in regulation of macrophage function, leading to a protective action against viral and bacterial infections. $^{5}$

Although detailed investigations has not been reported, some studies suggest that plant steroids such as $\beta$-sitosterol and stigmasterol may have an effect on immune function. For example, a supplemented diet with plant sterols lowered serum IL-6 concentrations. ${ }^{6,7}$

In a previous work, we reported that compounds (22S,23S)-3 $\beta$-bromo-5 $\alpha$-22,23-trihydroxystigmastan-6-

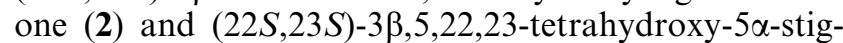
mastan-6-one (3) (Fig. 1), synthetic steroids structurally related to the brassinosteroids - plant growth hormonesprevented Herpes simplex virus type 1 (HSV-1) multiplication and viral spreading in a human conjunctival cell line (IOBA-NHC), with no cytotoxicity. ${ }^{8}$ Both compounds lack of anti-HSV activity in vivo, but decreased significantly the incidence of herpetic stromal keratitis 
<smiles>CC12CCC(O)CC13CCC1C(=O)CCCC1C3CCC2=O</smiles>

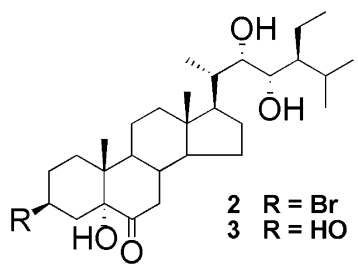

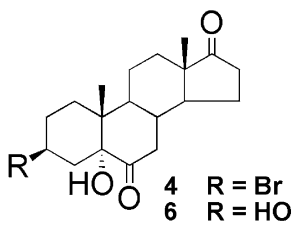

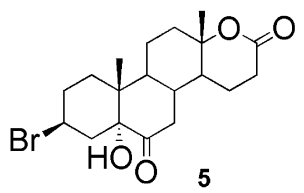
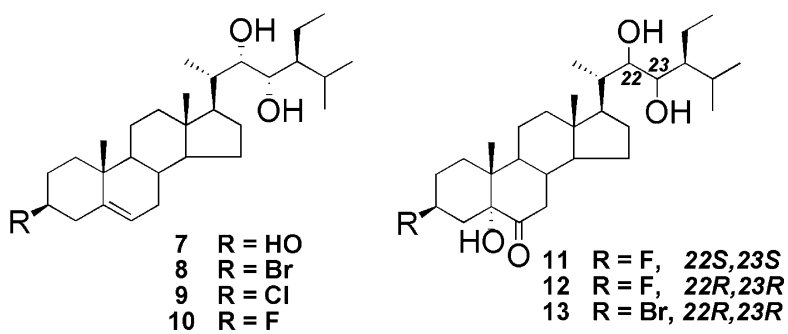

Figure 1. Structure of tested compounds.

(HSK) in infected mice. This fact led us to consider that these compounds may play a role in immune-mediated inflammation.

In this paper we demonstrate that compounds $\mathbf{2}$ and $\mathbf{3}$ have immunomodulating properties, and report the syntheses of a series of new steroidal compounds structurally related to $\mathbf{1}, \mathbf{2}$, and $\mathbf{3}$. Compounds $\mathbf{4 - 6}$ were obtained from DHEA (1) and compounds 7-13 from stigmasterol. The structures of the synthetic derivatives 4-13 are shown in Figure 1.
The ability of these compounds (1-13) to inhibit in vitro the amount of TNF- $\alpha$ produced by a macrophage cell line was assessed, and, from these results, a preliminary qualitative structure-activity relationship was established.

\section{Results and discussion}

\subsection{Syntheses}

Compounds 4-6 were obtained as depicted in Scheme 1. 3 3 -Bromoandrost-5-en-17-one ${ }^{9}$ (15) was synthesized from 1 in three steps. The $3 \beta$-mesyloxy derivate of 1 was first obtained, and then rearranged to the iso-steroid 14 with $\mathrm{KHCO}_{3}$ in acetone $/ \mathrm{H}_{2} \mathrm{O}$. Acid-promoted opening of the cyclopropane ring with aqueous $\mathrm{HBr}$ gave compound 15 with $72 \%$ total yield.

Treatment of $\mathbf{1 5}$ with $m$-chloroperoxybenzoic acid gave the $5 \alpha, 6$ aepoxide $\mathbf{1 6}$ as well as a small amount of the D-ring lactone 17, produced by the Baeyer-Villiger rearrangement of the $\mathrm{C}-17$ ketone.

Epoxide 16 was opened with Jones' reagent to give compound $\mathbf{4}$ with $87 \%$ yield. The same procedure on lactone $\mathbf{1 7}$ gave compound $\mathbf{5}$.

The $3 \beta$-acetate derivative of $\mathbf{1}$ was submitted to the epoxydation-oxidation sequence described for $\mathbf{4}$, followed by the alkaline hydrolysis of the $3 \beta$-acetate moiety to give compound $\mathbf{6}$.

Syntheses of compounds $\mathbf{7 - 1 0}$ are described in Scheme 2. Compound $\mathbf{1 8}$ was synthesized from stigmasterol in three steps, according to a previously reported procedure for the preparation of its $22 R, 23 R$ isomer. ${ }^{10} \mathrm{Com}$ -

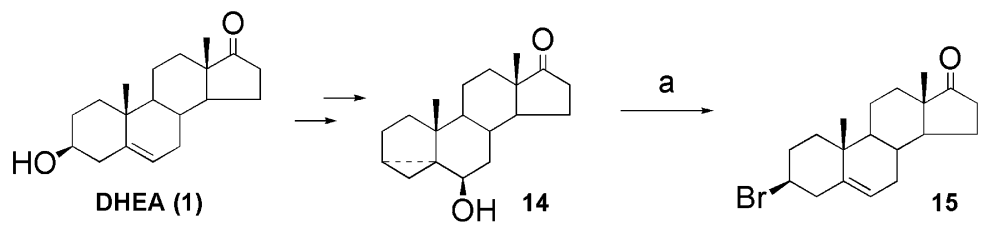

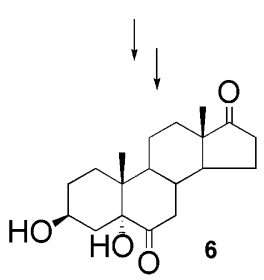

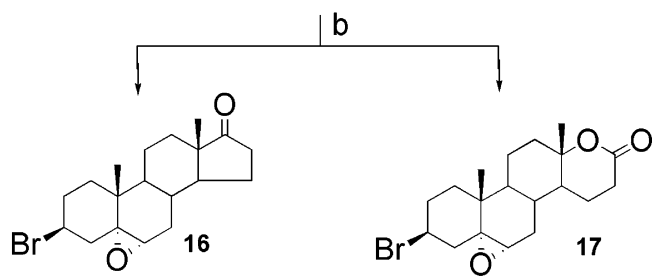

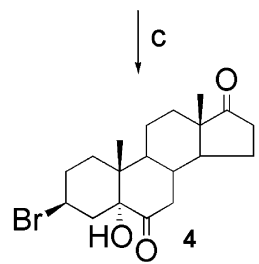

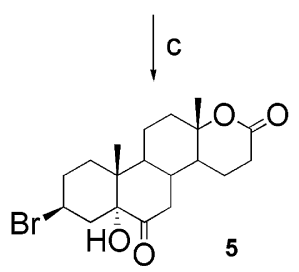

Scheme 1. Syntheses of compounds 4-6. Reagents and conditions: (a) $\mathrm{HBr}(48 \%$ aq)/toluene, rt; (b) $m$-CPBA/CHCl 3 , rt, 24 h; (c) Jones' reagent/ acetone, rt, $4 \mathrm{~h}$. 
pound $\mathbf{1 8}$ was isomerized with aqueous perchloric acid to give 7 with $87 \%$ yield.

In a similar way, compound $\mathbf{1 8}$ was treated alternatively with aqueous $\mathrm{HCl}, \mathrm{HBr}$, or $\mathrm{HF}$ ( $70 \%$ in pyridine) to afford the $3 \beta$-halo analogues $\mathbf{8}, \mathbf{9}$, and $\mathbf{1 0}$, respectively.

Scheme 3 shows the synthesis of compounds $\mathbf{1 1}$ and $\mathbf{1 2}$. The $3 \beta$-fluorosteroid $\mathbf{1 9}$ was obtained from stigmasterol by a sequence previously described, ${ }^{11}$ which uses $\mathrm{KMnO}_{4} / \mathrm{Fe}\left(\mathrm{NO}_{3}\right)_{3}$ as a regioselective epoxidation reagent. ${ }^{12}$ The $\beta$-oxirane ring was oxidized using the same methodology as described for compound 16; taking into account that the hydrolytic opening follows a transdiaxial path, the same $5 \alpha$-hydroxy-6-keto moiety was obtained in both cases. The resulting compound 20 was dihydroxylated according to Sharpless' procedure to give a mixture of the diasteromeric triols $\mathbf{1 1}$ and $\mathbf{1 2}$.

Compound 13, the $22 R, 23 R$ isomer of $\mathbf{2}$, was obtained as previously described. ${ }^{13}$ Configurations at $\mathrm{C}-22$ and $\mathrm{C}-23$ in the new analogues were established by comparison with NMR chemical shifts and coupling constants of known closely related structures. ${ }^{14}$

2.1.1. Biological assays. To determine the immunomodulatory activity of the compounds, we used a biological assay based on the ability of TNF- $\alpha$ to induce spontaneous lysis of murine L929 fibroblasts. ${ }^{15}$

Murine macrophages (J774A.1 cells) were incubated with lipopolysaccharide from Escherichia coli (LPS), in the absence or presence of different concentrations of the evaluated steroids. Supernatants were then harvested for TNF- $\alpha$ titration in L929 cells, and we determined the $\mathrm{IC}_{50}$ as the concentration of a given compound that reduced in $50 \%$ the TNF- $\alpha$ production. The assayed concentration ranges for all of the compounds were below their cytotoxic concentration. Dexamethasone was included as a positive control. ${ }^{16}$

The results are summarized in Table 1 .

Compounds $\mathbf{1 2}$ and $\mathbf{1 3}$ showed a high toxicity, and their $\mathrm{IC}_{50}$ was not determined. Compounds $\mathbf{5 , 9}$, and $\mathbf{1 0}$ were inactive at concentrations below their $\mathrm{CC}_{50}$.

Results show that DHEA (1) inhibits the amount of TNF- $\alpha$ produced by J774A.1 cells, supporting the suggestion that this steroid has a role as an in vivo immunomodulator. ${ }^{3,4}$ Furthermore, the synthetic steroids 2 and 3 proved to inhibit TNF- $\alpha$ production even more efficiently than 1 . This result may explain in part the fact that the topical application of these steroids can reduce the incidence of herpetic stromal keratitis in mice. ${ }^{8}$

Considering that compounds $\mathbf{2}$ and $\mathbf{3}$ have a branched side chain, characteristic of plant steroids, but not present in endogenous mammal steroids, it is remarkable their high inhibitory effect. In order to evaluate the relevance of this structural feature on the biological activity, we synthesized compounds $\mathbf{4}, \mathbf{6}$, and $\mathbf{7}$.

Table 1 shows that compounds $\mathbf{4}$ and $\mathbf{6}$ have a lower inhibitory effect than their corresponding stigmastane analogues $\mathbf{2}$ and $\mathbf{3}$. In the same way, DHEA (1) resulted

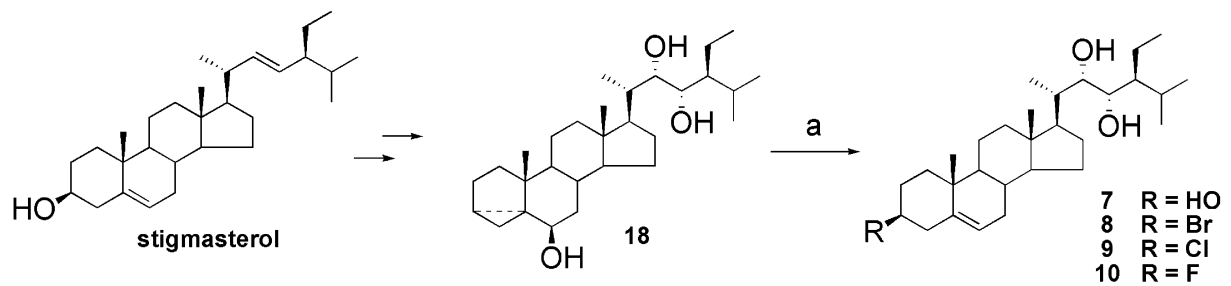

Scheme 2. Syntheses of compounds 7-10. Reagents and conditions: (a) For $7(\mathrm{R}=\mathrm{OH}) \mathrm{HClO}_{4}\left(70 \%\right.$ aq)/dioxane/water, $55^{\circ} \mathrm{C}, 1 \mathrm{~h}$. For $\mathbf{8}(\mathrm{R}=\mathrm{Br})$ : $\mathrm{HBr}(40 \% \mathrm{aq}) /$ toluene, $0{ }^{\circ} \mathrm{C}, 1 \mathrm{~h}$. For $9(\mathrm{R}=\mathrm{Cl})$ : $\mathrm{HCl}(35 \%$ aq $) /$ toluene, rt, $24 \mathrm{~h}$. For $10(\mathrm{R}=\mathrm{F})$ : $\mathrm{HF}(70 \%$ in Py $) /$ toluene, $0{ }^{\circ} \mathrm{C}, 0.5 \mathrm{~h}$.

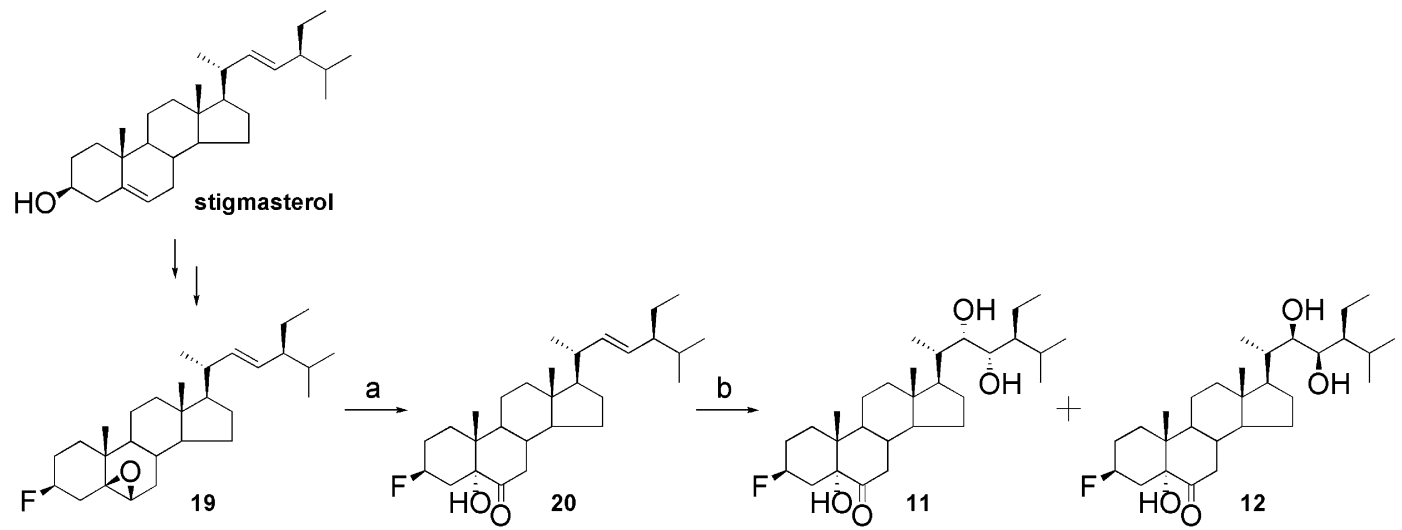

Scheme 3. Syntheses of compounds 11 and 12. Reagents and conditions: (a) Jones' reagent/acetone, $\mathrm{rt}, 1 \mathrm{~h} ;(\mathrm{b}) \mathrm{K}_{2} \mathrm{OsO} \mathrm{O}_{4} / \mathrm{K}_{4} \mathrm{Fe}\left(\mathrm{CN}_{6} / \mathrm{K}_{2} \mathrm{CO}_{3} /\right.$ (DHQD) $)_{2}-\mathrm{Phal} / \mathrm{MeSO}_{2} \mathrm{NH}_{2} / t-\mathrm{BuOH} / \mathrm{H}_{2} \mathrm{O} / \mathrm{THF}, 9$ days, $\mathrm{rt}$. 
Table 1. In vitro TNF- $\alpha$ production inhibition

\begin{tabular}{ll}
\hline Compound & $\mathrm{IC}_{50}(\mu \mathrm{M})$ \\
\hline $\mathbf{1}$ & 141 \\
$\mathbf{2}$ & 38 \\
$\mathbf{3}$ & 18 \\
$\mathbf{4}$ & 134 \\
$\mathbf{5}$ & Inactive \\
$\mathbf{6}$ & 109 \\
$\mathbf{7}$ & 35 \\
$\mathbf{8}$ & 144 \\
$\mathbf{9}$ & Inactive \\
$\mathbf{1 0}$ & Inactive \\
$\mathbf{1 1}$ & 47 \\
$\mathbf{1 2}$ & n.d. \\
$\mathbf{1 3}$ & n.d. \\
Dexamethasone & 48 \\
\hline
\end{tabular}

n.d., not determined (toxic).

less active than the synthetic compound 7 . In addition, the oxidation of the 17-keto moiety in $\mathbf{4}$ to give a ringD lactone (compound 5) reduces even more the activity.

The high toxicity of compounds $\mathbf{1 2}$ and 13, with the opposite stereochemistry at C22 and C23 than $\mathbf{1 1}$ and 2 , would be related to the configuration of the side chain diol.

The activity of $\mathbf{8 - 1 1}$ allowed to evaluate the effect of the $\mathrm{A}$ and $\mathrm{B}$ rings substitution pattern. The $\mathrm{IC}_{50}$ values shown on Table 1 suggest that compounds having a $5 \alpha$-hydroxy-6-keto moiety $(\mathbf{2}, \mathbf{3}, \mathbf{6}$, and $\mathbf{1 1})$ are more active than the corresponding derivatives with a $\Delta^{5}$ double bond $(\mathbf{8}, 7, \mathbf{1}$, and $\mathbf{1 0}$, respectively).

Change of the $3 \beta$-hydroxy group of compounds 3,6 and 7 by a $3 \beta$-halo group as in $\mathbf{4}$ and $8-11$ led to a decrease in the activity regardless of the rest of the structural features.

\section{Conclusions}

Previous investigations showed that $\beta$-sitosterol, a natural plant steroid having a stigmastane skeleton, have anti-inflammatory properties: the secretion of the cytokines interleukin- 6 and TNF- $\alpha$ by endotoxin activated human monocytes was significantly inhibited by this sterol. Thus, the authors suggest that $\beta$-sitosterol would have a role to play in the control of chronic inflammatory diseases. ${ }^{7}$

In this work we show that several synthetic stigmastanes are able to inhibit the TNF- $\alpha$ production, and that the effect is similar to, and even more potent than, that of DHEA, an endogenous immunomodulator androstane found in mammals. In addition, compounds 2, 3, 7, and $\mathbf{1 1}$ resulted as active as dexamethasone.

Results suggest that the observed decrease in the incidence of HSK in mice, and in the viral spreading in IOBA-NHC cells, would be linked to the immunomodulating properties of $\mathbf{2}$ and 3. Additional studies show that these compounds exert other immunomodulating effects, such as a significant inhibition of IL-6 production in macrophages. ${ }^{17}$ Preliminary results show that compound 2 reduces IL-6 and IL-8 production in human corneal and conjunctival cell lines stimulated with phorbol 12-myristate 13-acetate (PMA).

Finally, according to our preliminary analysis of the structure-activity relationships, the modulatory effect on the TNF- $\alpha$ production of these synthetic compounds could be related with the presence of a hydroxylated stigmastane side chain, having a $22 S, 23 S$ configuration, and with a $3 \beta, 5 \alpha$-dihydroxy-6-keto moiety in the steroidal ring system.

Detailed studies on the mechanism of action and on the design of new compounds with improved activities are under development.

\section{Experimental}

\subsection{Syntheses}

4.1.1. General. DHEA and stigmasterol were purchased from Sigma-Aldrich Chemical Co. EI-MS were measured in a VG Trio-2 or in a Shimadzu QP-5000 mass spectrometer at $70 \mathrm{eV}$ by direct inlet. ${ }^{1} \mathrm{H}$ NMR and ${ }^{13} \mathrm{C}$ NMR spectra were recorded in $\mathrm{CDCl}_{3}$ on a Bruker AM-500 at $500 \mathrm{MHz}$ and at $125.1 \mathrm{MHz}$, respectively, chemical shifts $(\delta)$ are given in ppm downfield from TMS as the internal standard. Coupling constant $(J)$ values are in $\mathrm{Hz} .{ }^{19} \mathrm{~F}$ NMR spectra were recorded on a Bruker AM-500 at $470.4 \mathrm{MHz}$, and chemical shifts $(\delta)$ are given in ppm upfield from $\mathrm{CFCl}_{3}$ as the internal standard. All solvents and reagents were of analytical grade.

The preparations reported below are of compounds that were either new or synthesized using adaptations of literature methods. All substrates gave satisfactory analytical and spectral data. All new compounds gave satisfactory NMR and mass spectral/combustion analysis data.

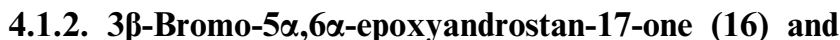

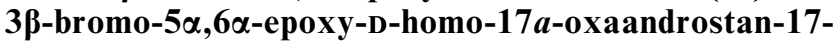
one (17). To a solution of $3 \beta$-bromoandrost-5-en-17one $^{9}(15)(200 \mathrm{mg}, 0.57 \mathrm{mmol})$ in $\mathrm{CHCl}_{3}(15 \mathrm{~mL}), \mathrm{m}$ chloroperoxybenzoic acid $(0.4 \mathrm{~g}, 2.3 \mathrm{mmol})$ was added at room temperature. The mixture was stirred at room temperature for $24 \mathrm{~h}$. The solution was then diluted with $\mathrm{CH}_{2} \mathrm{Cl}_{2}$, treated with $10 \%$ aqueous $\mathrm{NaOH}$, and the aqueous layer was extracted with several portions of $\mathrm{CH}_{2} \mathrm{Cl}_{2}$. The combined organic extracts were washed with water, dried with anhydrous $\mathrm{MgSO}_{4}$, filtered, and evaporated to leave a crude solid, which was column chromatographed (methylene chloride/ methyl alcohol, 100:1) to afford $80 \%$ of $3 \beta$-bromo$5 \alpha, 6 \alpha$-epoxyandrostan-17-one (16) and $15 \%$ of $3 \beta$-bromo-5 $\alpha, 6 \alpha$-epoxy-D-homo-17a-oxaandrostan-17-one (17).

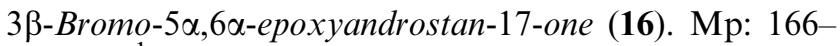
$168{ }^{\circ} \mathrm{C} ;{ }^{1} \mathrm{H}$ NMR: $4.22(\mathrm{H}-3 \alpha, 1 \mathrm{H}, \mathrm{m}), 2.96(\mathrm{H}-6 \beta$, 
$1 \mathrm{H}, \mathrm{d}, J=4 \mathrm{~Hz}), 1.13(\mathrm{H}-19,3 \mathrm{H}, \mathrm{s}), 0.82$ (H-18, 3H, s); ${ }^{13} \mathrm{C}$ NMR: 220.9 (C-17), 66.5 (C-5), 59.0 (C-6), 51.8, 48.0 (C-3), 47.6, 42.8, 42.2, 35.7, 35.3, 34.9, 33.6, 31.0, 29.4, 27.7, 21.6, 19.8, 15.8 (C-19), 13.5 (C-18); MS (m/ $z)$ : 366-368 $\left(\mathrm{M}^{+}, \quad \mathrm{C}_{19} \quad \mathrm{H}_{27} \mathrm{BrO}_{2}, \quad 20 \%\right), \quad 348-350$ $\left(\mathrm{M}-\mathrm{H}_{2} \mathrm{O}, 18 \%\right), 287(\mathrm{M}-\mathrm{Br}, 100 \%)$. Anal. calcd for $\mathrm{C}_{19} \mathrm{H}_{27} \mathrm{BrO}_{2}$ : C, 62.13; H, 7,41. Found: C, 62.08; H, 7.38

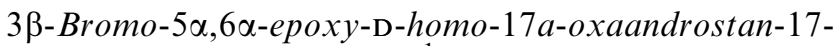
one (17). Mp: $171-173{ }^{\circ} \mathrm{C} ;{ }^{1} \mathrm{H}$ NMR: $4.20(\mathrm{H}-3 \alpha, 1 \mathrm{H}$, m), $2.96(\mathrm{H}-6 \beta, 1 \mathrm{H}, \mathrm{d}, J=4 \mathrm{~Hz}), 1.26(\mathrm{H}-18,3 \mathrm{H}, \mathrm{s})$, 1.07 (H-19, 3H, s); ${ }^{13} \mathrm{C}$ NMR: 171.1 (C-17), 82.6 (C13), 66.2 (C-6), 58.7 (C-5), 47.6 (C-3), 46.9, 41.9, 41.8, $38.6,35.0,34.8,33.4,32.3,28.7,28.1,21.2,20.1,19.7$ (C-18), 15.6 (C-19); $\mathrm{MS}(\mathrm{m} / \mathrm{z})$ : 382-384 ( ${ }^{+}, \mathrm{C}_{19} \mathrm{H}_{27}$ $\left.\mathrm{BrO}_{3}, 13 \%\right), 303(\mathrm{M}-\mathrm{Br}, 87 \%)$. Anal. calcd for $\mathrm{C}_{19} \mathrm{H}_{27} \mathrm{BrO}_{3}$ : C, 59.53; $\mathrm{H}, 7,10$. Found: C, 59.50; H, 7.12 .

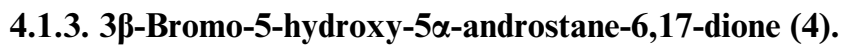
Jones' reagent $(0.5 \mathrm{ml})$ was added dropwise to a stirred solution of $16(250 \mathrm{mg}, 0.68 \mathrm{mmol})$ in acetone $(25 \mathrm{ml})$. After $4 \mathrm{~h}$, isopropyl alcohol was added to stop the reaction. The mixture was neutralized with solid sodium bicarbonate, filtered, and the solvent was evaporated under reduced pressure. The crude residue was purified by column chromatography (methylene chloride/methyl alcohol, 100:1) to afford $3 \beta$-bromo-5 $\alpha$-hydroxyandrostane-6,17-dione (4) in 87\% yield.

Mp: 205-208 ${ }^{\circ} \mathrm{C}$ (dec.); ${ }^{1} \mathrm{H}$ NMR: 4.33 (H-3 $\left.\alpha, 1 \mathrm{H}, \mathrm{m}\right)$, 0.87 (H-19, 3H, s), 0.86 (H-18, 3H, s); ${ }^{13} \mathrm{C}$ NMR: 220.4 (C-17), 211.1 (C-6), 80.7 (C-5), 51.2, 48.2 (C-3), $47.5,44.5,42.2,40.5,38.7,36.6,35.6,32.7,32.1,31.1$, 21.5, 20.3, 13.9 (C-19), 13.7 (C-18); MS ( $\mathrm{m} / \mathrm{z}): 382-384$ $\left(\mathrm{M}^{+}, \mathrm{C}_{19} \mathrm{H}_{27} \quad \mathrm{BrO}_{3}, 90 \%\right), 303(\mathrm{M}-\mathrm{Br}, 7 \%), 275$ $(53 \%), 220$ (75\%); Anal. calcd for $\mathrm{C}_{19} \mathrm{H}_{27} \mathrm{BrO}_{3}$ : C, 59.53; H, 7,10. Found: C, 59.48; H, 7.08.

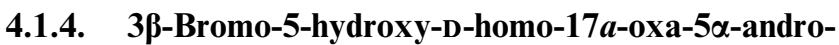
stane-6,17-dione (5). Compound 5 was obtained in a similar way as compound 4. Oxidation of $\mathbf{1 7}$ afforded, after column chromatography (methylene chloride/methyl

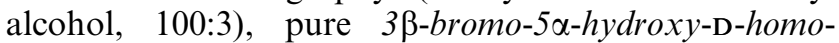
17a-oxaandrostane-6,17-dione (5) in 90\% yield. Mp: 213-215 ${ }^{\circ} \mathrm{C}$ (dec.); ${ }^{1} \mathrm{H}$ NMR: 4.30 (H-3a, 1H, m), 1.30 $(\mathrm{H}-18,3 \mathrm{H}, \mathrm{s}), 0.82(\mathrm{H}-18,3 \mathrm{H}, \mathrm{s}) ;{ }^{13} \mathrm{C}$ NMR: $210.0(\mathrm{C}-$ 6), 171.1 (C-17), 82.8 (C-13), 80.3 (C-5), 46.9 (C-3), $46.2,43.4,41.5,40.2,39.1,38.9,38.7,32.6,32.0,28.4$, 21.6, 20.1, 19.6 (C-18), 13.8 (C-19); MS ( $\mathrm{m} / \mathrm{z}): 398-400$ $\left(\mathrm{M}^{+}, \mathrm{C}_{19} \mathrm{H}_{27} \mathrm{BrO}_{4}, 95 \%\right), 319(\mathrm{M}-\mathrm{Br}, 9 \%), 291(57 \%)$, $236(67 \%)$. Anal. calcd for $\mathrm{C}_{19} \mathrm{H}_{27} \mathrm{BrO}_{4}$ : C, 57.15; $\mathrm{H}$, 6,82. Found: C, 57.04; H, 6.80.

4.1.5. 3ß,5-Dihydroxy-5 $\alpha$-androstane-6,17-dione (6). ${ }^{18}$ Mp: $290-293{ }^{\circ} \mathrm{C}$ (dec.) (Lit.: $282-284^{\circ} \mathrm{C}$ ); ${ }^{1} \mathrm{H}$ NMR: $3.92(\mathrm{H}-3 \alpha, 1 \mathrm{H}, \mathrm{m}), 0.86$ (H-18, 3H, s), 0.81 (H-18, 3H, s); ${ }^{13} \mathrm{C}$ NMR: 220.9 (C-1), 213.3 (C-6), 79.8 (C-5), 66.6 (C-3), 51.2, 48.2, 44.3, 42.3, 40.3, 36.7, 35.6, 35.3, 31.1, 29.9, 29.8, 21.5, 20.5, 13.7 (C-18, ó C-19), 13.6 (C-18, ó C-19); $\mathrm{MS}(\mathrm{m} / \mathrm{z}): 320\left(\mathrm{M}^{+}, \mathrm{C}_{19} \mathrm{H}_{28} \mathrm{O}_{4}, 76 \%\right), 302$ $\left(\mathrm{M}-\mathrm{H}_{2} \mathrm{O}, 20 \%\right), 220(100 \%), 205$ (30\%). Anal. calcd for $\mathrm{C}_{19} \mathrm{H}_{28} \mathrm{O}_{4}$ : C, 71.22; H, 8.81. Found: C, 71.30; H, 8.85.

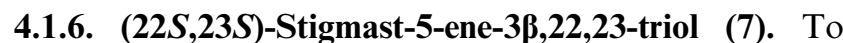
$200 \mathrm{mg}$ of $(22 S, 23 S)-3 \alpha, 5$-cyclostigmasta-6 $\beta, 22,23$-triol ${ }^{10}$ (18) dissolved in $15 \mathrm{ml}$ of dioxane $0.5 \mathrm{ml}$ of water and $0.05 \mathrm{ml}$ of $\mathrm{HClO}_{4}(70 \% \mathrm{aq})$ were added. The solution was stirred and heated at $55^{\circ} \mathrm{C}$ for $1 \mathrm{~h}$, cooled, and poured into $50 \mathrm{ml}$ of brine. The mixture was extracted with dichloromethane $(3 \times 15 \mathrm{ml})$, and the organic phase was dried and evaporated under reduced pressure.

Purification of the crude product by silica gel column chromatography (hexane/EtOAc, 9:1) allowed to obtain $175 \mathrm{mg}$ of compound 7 (87\% yield).

Mp: $163{ }^{\circ} \mathrm{C} ;{ }^{1} \mathrm{H}$ NMR: $5.35(\mathrm{H}-6,1 \mathrm{H}, \mathrm{m}), 3.59(\mathrm{H}-22$ and $\mathrm{H}-23,2 \mathrm{H}, \mathrm{m}), 3.50(\mathrm{H}-3 \alpha, 1 \mathrm{H}, \mathrm{m}), 1.01$ (H-19, $3 \mathrm{H}, \mathrm{s}), 0.93-1.03$ (H-26, H-27 and $\mathrm{H}-29,9 \mathrm{H}, \mathrm{m}), 0.87$ $(\mathrm{H}-21,3 \mathrm{H}, \mathrm{d}, J=6.7), 0.72(\mathrm{H}-18,3 \mathrm{H}, \mathrm{s}) ;{ }^{13} \mathrm{C}$ NMR: 140.7 (C-5), 121.4 (C-6), 71.9 (C-22), 71.3 (C-3), 70.2 (C-23), 56.3, 52.5, 50.0, 49.4, 42.7, 42.3, 41.9 (C-4), 39.6, 37.1, 36.4, 31.8, 31.7, 31.2, 27.9, 26.7, 24.4, 21.7, 20.9, 19.2 (C-19), 18.4, 17.5, 14.3, 13.8, 11.6 (C-18); Anal. calcd for $\mathrm{C}_{29} \mathrm{H}_{50} \mathrm{O}_{3}$ : C, 77.97; H, 11.28. Found: C, 77.85; H, 11.09.

4.1.7. (22S,23S)-3ß-chlorostigmast-5-ene-22,23-diol (9). One hundred miligrams of compound $\mathbf{1 8}$ were dissolved in $10 \mathrm{ml}$ of toluene, cooled in an ice bath and stirred. $\mathrm{HCl}(0.05 \mathrm{ml})(35 \% \mathrm{aq})$ was added and the solution was stirred for 1 day. The mixture was extracted with $\mathrm{NaHCO}_{3}(5 \%$ aq, $3 \times 15 \mathrm{ml})$, and the organic phase was dried and evaporated.

Purification of the crude product by silica gel column chromatography (hexane/EtOAc, 95:5) allowed to obtain $70 \mathrm{mg}$ of 9 (F16, 78\% yield).

Mp: $158^{\circ} \mathrm{C} ;{ }^{1} \mathrm{H}$ NMR: $5.37(\mathrm{H}-6,1 \mathrm{H}, \mathrm{m}), 3.76(\mathrm{H}-3 \alpha$, $1 \mathrm{H}, \mathrm{m}), 3.61(\mathrm{H}-22$ and $\mathrm{H}-23,2 \mathrm{H}, \mathrm{m}), 2.56(\mathrm{H}-4 \alpha, 1 \mathrm{H}$, $\mathrm{m}), 2.48(\mathrm{H}-4 \beta, 1 \mathrm{H}, \mathrm{m}), 1.03(\mathrm{H}-19,3 \mathrm{H}, \mathrm{s}), 0.95-1.03$ $(\mathrm{H}-26, \mathrm{H}-27$ and $\mathrm{H}-29,9 \mathrm{H}, \mathrm{m}), 0.87(\mathrm{H}-21,3 \mathrm{H}, \mathrm{d}$, $J=6.7), 0.72(\mathrm{H}-18,3 \mathrm{H}, s) ;{ }^{13} \mathrm{C}$ NMR: $140.9(\mathrm{C}-5)$, 122.3 (C-6), 72.3 (C-22), 70.7 (C-23), 60.2 (C-3), 56.3, 52.7, 50.0, 49.7, 43.4, 42.9, 42.4, 39.7, 39.1, 36.4, 33.4, $31.8,28.0,26.9,24.5,21.7,21.0,19.2$ (C-19), 18.6, 17.7, 14.4, 14.2, 11.8 (C-18); Anal. calcd for $\mathrm{C}_{29} \mathrm{H}_{49} \mathrm{ClO}_{2}$ : C, 74.88; H, 10.62. Found: C, 74.79; H, 10.55 .

4.1.8. (22S,23S)-3 $\beta$-Bromostigmast-5-ene-22,23-diol (8). One hundred miligram of compound $\mathbf{1 8}$ dissolved in $20 \mathrm{ml}$ of toluene was treated with $0.1 \mathrm{ml}$ of $\mathrm{HBr}(40 \%$ aq) as described above. The mixture was stirred for $1 \mathrm{~h}$, and yielded, after work-up, a crude product that was purified by column chromatography (hexane/ EtOAc, 95:5) to yield $123 \mathrm{mg}$ of $\mathbf{8}$ (81\% yield). Mp: $181{ }^{\circ} \mathrm{C} ;{ }^{1} \mathrm{H}$ NMR: $5.36(\mathrm{H}-6,1 \mathrm{H}, \mathrm{m}), 3.92(\mathrm{H}-3 \alpha, 1 \mathrm{H}$, $\mathrm{m}), 3.61$ (H-22 and $\mathrm{H}-23,2 \mathrm{H}, \mathrm{m}), 2.74(\mathrm{H}-4 \alpha, 1 \mathrm{H}$, $\mathrm{ddd}, J=2.2,4.8,13.5), 2.58(\mathrm{H} \beta-4,1 \mathrm{H}, \mathrm{m}), 1.04$ (H-19, 3H, s), 0.95-1.03 (H-26, H-27 and $\mathrm{H}-29,9 \mathrm{H}$, m), $0.88(\mathrm{H}-21,3 \mathrm{H}, \mathrm{d}, J=6.7), 0.72(\mathrm{H}-18,3 \mathrm{H}, s) ;{ }^{13} \mathrm{C}$ NMR: 141.6 (C-5), 122.2 (C-6), 72.3 (C-22), 70.7 (C23), 56.3, 52.7 (C-3), 52.4, 50.1, 49.6, 44.3, 42.9, 42.4, $40.3,39.6,36.4,34.3,31.7,28.0,26.9,24.5,21.7,20.9$, 
19.2 (C-19), 18.6, 17.8, 14.4, 14.2, 11.7 (C-18); Anal. calcd for $\mathrm{C}_{29} \mathrm{H}_{49} \mathrm{BrO}_{2}$ : C, 68.35; H, 9.69. Found: C, $68.41 ; \mathrm{H}, 9.81$.

4.1.9. (22S,23S)-3ß-Fluorostigmast-5-ene-22,23-diol (10). Fifty miligrams of compound $\mathbf{1 8}$ dissolved in $10 \mathrm{ml}$ of toluene was treated with $0.05 \mathrm{ml}$ of $\mathrm{HF}(70 \%$ in pyridine) at $0{ }^{\circ} \mathrm{C}$. The mixture was stirred for $30 \mathrm{~min}$, and poured on brine. The usual work-up and chromatographic purification allowed to obtain 10 (72\% yield).

Mp: $140{ }^{\circ} \mathrm{C} ;{ }^{1} \mathrm{H}$ NMR: 5.39 (H-6, 1H, m), 4.40 (H-3 $\alpha$, $\left.1 \mathrm{H}, \mathrm{dm},{ }^{2} J_{\mathrm{HF}}=50.7\right), 3.62(\mathrm{H}-22$ and $\mathrm{H}-23,2 \mathrm{H}, \mathrm{m})$, 2.44 (H-4, 2H, m), 1.03 (H-19, 3H, s), 0.94-1.04 (H26, $\mathrm{H}-27$ and $\mathrm{H}-29,9 \mathrm{H}, \mathrm{m}), 0.88(\mathrm{H}-21,3 \mathrm{H}, \mathrm{d}$, $J=7.0), 0.72(\mathrm{H}-18,3 \mathrm{H}, \mathrm{s}) ;{ }^{13} \mathrm{C}$ NMR: $139.4(\mathrm{C}-5, \mathrm{~d}$, $\left.{ }^{3} J_{\mathrm{CF}}=12.3\right), 122.9(\mathrm{C}-6), 92.8\left(\mathrm{C}-3, \mathrm{~d},{ }^{1} J_{\mathrm{CF}}=174.3\right)$, 72.2 (C-22), 70.6 (C-23), 56.3, 52.6, 49.9, 49.6, 42.8, $42.4,39.6,39.4\left(\mathrm{C}-4, \mathrm{~d},{ }^{3} J_{\mathrm{CF}}=19.4\right), 36.5,36.3(\mathrm{C}-1$, $\left.\mathrm{d},{ }^{3} J_{\mathrm{CF}}=11.4\right), 31.8,28.7\left(\mathrm{C}-2, \mathrm{~d},{ }^{2} J_{\mathrm{CF}}=17.6\right), 28.0$, $26.9,24.5,21.7,21.1,19.3$ (C-19), 18.5, 17.7, 14.5, 14.1, 11.7 (C-18); ${ }^{19}$ F NMR: -168.0 (m); Anal. calcd for $\mathrm{C}_{29} \mathrm{H}_{49} \mathrm{FO}_{2}$ : C, 77.63; H, 11.01. Found: C, 77.51; $\mathrm{H}, 11.10$.

4.1.10. (22E)-3 $\beta$-Fluoro-5-hydroxy-5 $\alpha$-stigmast-22-en-6one (20). Jones' reagent $(0.5 \mathrm{ml})$ was added dropwise to a stirred solution of ( $22 E)$-3 $\beta$-fluoro- $5 \beta, 6 \beta$-epoxystigmast-22-ene $^{11}$ (compound 19, $300 \mathrm{mg}, 0.70 \mathrm{mmol}$ ) in acetone $(25 \mathrm{ml})$. After $1 \mathrm{~h}$, isopropyl alcohol was added to stop the reaction. The mixture was neutralized with solid sodium bicarbonate, filtered, and the solvent was evaporated under reduced pressure. The crude residue was purified by column chromatography (hexane/ethyl acetate, 9:1) to afford $\mathbf{2 0}$ in $83 \%$ yield.

Mp: $147{ }^{\circ} \mathrm{C} ;{ }^{1} \mathrm{H}$ NMR: $5.15(\mathrm{H}-22,1 \mathrm{H}, \mathrm{dd}, J=15.1,8,6)$, $5.02(\mathrm{H}-23,1 \mathrm{H}, \mathrm{dd}, J=15.1,8,6), 4.83(\mathrm{H}-3 \alpha, 1 \mathrm{H}, \mathrm{dm}$, $\left.{ }^{2} J_{\mathrm{HF}}=50\right), 2.72(\mathrm{H}-7 \alpha, 1 \mathrm{H}, \mathrm{dd}, J=12.6,12.5), 0.92-0.99$ (H-26, H-27 and H-29, 9H, m), 0.91 (H-21, 3H, d, $J=6.8), 0.82$ (H-19, 3H, s), 0.67 (H-18, 3H, s); ${ }^{13} \mathrm{C}$ NMR: 212.9 (C-6), 137.7 (C-22); 129.0 (C-23); 90.1 $\left(\mathrm{C}-3,{ }^{1} J_{\mathrm{CF}}=171.1\right), 81.1\left(\mathrm{C}-5,{ }^{3} J_{\mathrm{CF}}=12\right), 56.0,55.5$, $50.8,43.9,42.6,42.0,41.5,40.0,39.1,37.0,33.8$ (C-4, $\left.{ }^{2} J_{\mathrm{CF}}=21.5\right), 31.4,30.0,\left(\mathrm{C}-2,{ }^{2} J_{\mathrm{CF}}=12\right), 28.3,24.9$, 23.6, 20.9, 20.7, 20.7, 18.6, 13.6 (C-19); 11.9, 11.8 (C18); ${ }^{19}$ F NMR: $-172.6(\mathrm{~m})$; Anal. calcd for $\mathrm{C}_{29} \mathrm{H}_{47} \mathrm{FO}_{2}$ : C, 77.98; H, 10.61. Found: C, 78.05; H, 10.52.

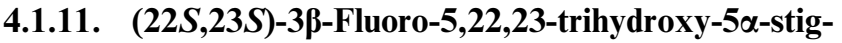
mastan-6-one (11) and $(22 R, 23 R)-3 \beta$-fluoro-5,22,23-trihydroxy-5 $\alpha$-stigmastan-6-one (12). A mixture of 20 (130 mg, $0.28 \mathrm{mmol})$, tert-butanol/water $(1: 1,20 \mathrm{ml})$, (DHQD) $)_{2}$-Phal $(120 \mathrm{mg}, 0.16 \mathrm{mmol})$, methanesulfonamide (90 mg, $0.52 \mathrm{mmol}$ ), potassium ferricyanide (300 $\mathrm{mg}, 0.92 \mathrm{mmol}$ ), potassium carbonate (124 mg, $0.90 \mathrm{mmol}$ ), and potassium osmate dihydrate (14 mg, $0.04 \mathrm{mmol})$ was stirred at room temperature for 9 days. An excess of $\mathrm{NaHSO}_{3}$ was added until no evolution of bubbles was observed. Layers were separated and the aqueous phase was thoroughly extracted with EtOAc. Combined organic layers were washed with $0.25 \mathrm{M} \mathrm{H}_{2} \mathrm{SO}_{4}$ and $2 \% \mathrm{NaOH}$. Purifi- cation by column chromatography $\left(\mathrm{CH}_{2} \mathrm{Cl}_{2}\right.$ /acetonitrile gradient) allowed to obtain $70 \mathrm{mg}$ of $(22 \mathrm{~S}$, $23 S)$-3 $\beta$-fluoro-5,22,23-trihydroxy-5 $\alpha$-stigmastan-6-one (11).

Mp: $188^{\circ} \mathrm{C}$; ${ }^{1} \mathrm{H}$ NMR: $4.83(\mathrm{H}-3 \alpha, 1 \mathrm{H}, 1 \mathrm{H}, \mathrm{dm}$, $\left.{ }^{2} J_{\mathrm{HF}}=50.5\right), 3.60(\mathrm{H}-22$ and $\mathrm{H}-23,1 \mathrm{H}, \mathrm{m}, 2.72(\mathrm{H}-7 \alpha$, $1 \mathrm{H}, \mathrm{dd}, J=12.6$ and 12.5), 0.92-0.99 (H-26, H-27 and $\mathrm{H}-29,9 \mathrm{H}, \mathrm{m}), 0.91(\mathrm{H}-21,3 \mathrm{H}, \mathrm{d}, J=6.8), 0.82(\mathrm{H}-19$, $3 \mathrm{H}, s), 0.67$ (H-18, 3H, s); ${ }^{13} \mathrm{C}$ NMR: 211.4 (C-6), 90.2 $\left(\mathrm{C}-3,{ }^{1} J_{\mathrm{CF}}=171.0\right), 81.1 \quad\left(\mathrm{C}-5,{ }^{3} J_{\mathrm{CF}}=12\right), 72.1 \quad(\mathrm{C}-$ 22), 70.6 (C-23), 55.9, 52.5, 49.6, 44.3, 43.6, 42.4, 42.2, $41.5,39.5,37.1,33.8\left(\mathrm{C}-4,{ }^{2} J_{\mathrm{CF}}=21.5\right), 29.3(\mathrm{C}-2$, $\left.{ }^{2} J_{\mathrm{CF}}=12\right), 27.8,27.6,27.3,26.9,24.1,21.7,21.4,18.5$, 17.7, 14.4, 14.0, 11.9; ${ }^{19}$ F NMR: -172.3 (m); Anal. calcd for $\mathrm{C}_{29} \mathrm{H}_{49} \mathrm{FO}_{4}$ : C, 72.46; H, 10.27. Found: C, 72.39; H, 10.35 .

4.1.12. Further elution yielded $32 \mathrm{mg}$ of $(22 R, 23 R)-3 \beta-$ fluoro-5,22,23-trihydroxy-5 $\alpha$-stigmastan-6-one (12). Mp: $190{ }^{\circ} \mathrm{C} ;{ }^{1} \mathrm{H}$ NMR: $4.82 \quad(\mathrm{H}-3 \alpha, 1 \mathrm{H}, 1 \mathrm{H}, \mathrm{dm}$, $\left.{ }^{2} J_{\mathrm{HF}}=50.7\right), 3.58(\mathrm{H}-22,1 \mathrm{H}, \mathrm{dd}, J=8.4$ and 1.3$), 3.71$ $(\mathrm{H}-23,1 \mathrm{H}, \mathrm{dd}, J=8.4$ and 1.3$), 2.71(\mathrm{H}-7 \alpha, 1 \mathrm{H}$, dd, $J=12.6$ and 12.5), 0.92-0.99 (H-26, H-27 and H-29, 9H, m), $0.91(\mathrm{H}-21,3 \mathrm{H}, d, J=6.8), 0.82(\mathrm{H}-19,3 \mathrm{H}, s)$, 0.67 (H-18, 3H, s); ${ }^{13} \mathrm{C}$ NMR: 212.8 (C6), 90.1 (C-3, $\left.{ }^{1} J_{\mathrm{CF}}=171.1\right), 80.9\left(\mathrm{C}-5,{ }^{3} J_{\mathrm{CF}}=12\right), 74.1(\mathrm{C}-22), 72.2$ (C-23), 55.8, 55.5, 46.4, 43.9, 42.6, 42.0, 41.6, 39.1, $37.0,36.8,33.9\left(\mathrm{C}-4,{ }^{2} J_{\mathrm{CF}}=20\right), 30.1,29.5 \quad(\mathrm{C}-2$, $\left.{ }^{2} J_{\mathrm{CF}}=12\right), 28.8,28.3,23.6,20.9,20.7,19.2,19.0,13.6$, 13.2, 11.8, 11.6; ${ }^{19} \mathrm{~F}$ NMR: -172.1 (m); Anal. calcd for $\mathrm{C}_{29} \mathrm{H}_{49} \mathrm{FO}_{4}$ : C, 72.46; $\mathrm{H}, 10.27$. Found: C, 72.41; $\mathrm{H}, 10.31$.

4.1.13. Biological assays. $T N F-\alpha$ mouse recombinant expressed in $E$. coli was purchased from Sigma. LPS from E. coli serotype 055: B5 was purchased from Sigma.

The mouse fibroblastic cell line L929 was grown in Eagle's minimal essential medium supplemented with $5 \%$ inactivated fetal bovine serum (MEM 5\%), and $50 \mu \mathrm{g} / \mathrm{ml}$ gentamycin, and maintained in MEM supplemented with $1.5 \%$ inactivated fetal bovine serum (MEM 1.5\%). Murine macrophage cell line J774A.1 was kindly provided by Dr. Osvaldo Zabal (INTACastelar, Buenos Aires) and grown in RPMI 1640 medium supplemented with $10 \%$ inactivated fetal bovine serum and $50 \mu \mathrm{g} / \mathrm{ml}$ gentamycin, and maintained in RPMI supplemented with $2 \%$ inactivated fetal bovine serum.

The 50\% cytotoxic concentration $\left(\mathrm{CC}_{50}\right)$ for $\mathrm{L} 929$ cells was determined. Tested compounds were added to confluent non-growing cells in concentrations ranging from 2 to $400 \mu \mathrm{M}$ and, after $24 \mathrm{~h}$ of incubation at $37^{\circ} \mathrm{C}$, a MTT colorimetric assay was performed. ${ }^{19}$

Murine macrophages ( $\mathbf{J} 774$ cell line) were incubated at $37^{\circ} \mathrm{C}$ with $100 \mathrm{ng} / \mathrm{mL}$ of LPS, in the absence or presence of different concentrations of the evaluated steroids.

Measurement of TNF- $\alpha$ bioactivity was performed with the L929 cell-based bioassay, ${ }^{20}$ with minor 
modifications. L929 cells were grown in 96-well culture $\left(2 \times 10^{4}\right.$ cells/well $)$ for $24 \mathrm{~h}$ at $37^{\circ} \mathrm{C}$. The culture supernatants were removed and substituted with the samples to be assayed for TNF- $\alpha$ content in successive twofold dilutions and incubated at $38.5^{\circ} \mathrm{C}$ with $5 \mu \mathrm{g} / \mathrm{ml}$ of AcD for $22 \mathrm{~h}$. Cells were fixed in 10\% formaldehyde and stained with crystal violet $0.05 \%$. Measurement of light absorbance at $580 \mathrm{~nm}$ and comparison with a TNF- $\alpha$ standard dilution series allowed assessment of TNF- $\alpha$ activity. The bioassay was specific for TNF- $\alpha$ since the activity was neutralized with a neutralizing antibody against TNF- $\alpha$.

\section{Acknowledgments}

This work was supported by grants from the Universidad de Buenos Aires (UBACyT X-190 and Agencia Nacional de Promoción Científica y Técnica (ANPCYT) PICT 12307/02. We are grateful to UMYMFOR (UBACONICET) for the analytical and spectroscopic determinations.

\section{References and notes}

1. Corral, L. G.; Kaplan, G. Ann. Rheum. Dis. 1999, 58, 107.

2. Magna, A. M.; Takiya, C. M.; Aruda, L. B.; Pascarelli, B.; Gomes, R. N.; Faria, H. C.; Lima, L. M.; Barreiro, E. J. Int. Immunopharmacol. 2005, 5, 485.

3. Kipper-Gaiperin, M.; Galilly, R.; Danenberg, H. D.; Brenner, T. Int. J. Dev. Neurosci. 1999, 17, 765.

4. Kim, S. K.; Shin, M. S.; Jung, B. K.; Shim, J. Y.; Won, H. S.; Lee, P. R.; Kim, A. . J. Reprod. Immunol. 2006, 70, 71.
5. Loria, R. M.; Regelson, W.; Padgett, D. A. In The Biologic Role of Dehydroepiandrosterone DHEA; Kalimi, M., Regelson, W., Eds.; Walter De Gruyter: New York, 1990; pp 107-130.

6. De Jonga, A.; Plata, J.; Mensink, R. P. J. Nutr. Biochem. 2003, 14, 362 .

7. Bouic, P. J. D. Curr. Opin. Clin. Nutr. Metab. Care 2001, 4,471

8. Michelini, F. M.; Ramírez, J. A.; Berra, A.; Galagovsky, L. R.; Alché, L. E. Steroids 2004, 69, 713.

9. Bose, A. K.; Bansi, L. Tetrahedron Lett. 1973, 40, 3937.

10. Hellrung, B.; Voigt, B.; Schmidt, J.; Adam, G. Steroids 1997, 62, 415.

11. Galagovsky, L. R.; Gros, E. G.; Ramírez, J. A. Phytochemistry 2001, 58, 973.

12. Syamala, A.; Baskaran, S.; Chandrasekaran, S. J. Org. Chem. 1992, 57, 1928.

13. Ramírez, J. A.; Teme Centurión, O. M; Gros. E. G.; Galagovsky, L. R. Steroids 2000, 65, 329.

14. Porzel, A.; Marquandt, V.; Adam, G. Magn. Reson. Chem. 1992, 30, 651.

15. Hogan, M. M.; Vogel, S. N.. In Current Protocols in Immunology; Coligan, J. E., Kruisbeek, A. M., Margulies, D. H., Shevach, E. M., Strober, W., Eds.; Wiley: New York, 1992; Vol. 6, p 1.

16. Joyce, D. A.; Steer, J. H.; Abraham, L. J. Inflamm. Res. 1997, 46, 447.

17. Michelini, F. M.; Berra, A.; Alché, L. E. J. Steroid Biochem. Mol. Biol. accepted for publication.

18. Dawidar, A. M.; Saleh, A. A.; Abdel-Malek, M. M. Z. Naturforsch., B: Anorg. Chem., Org. Chem. 1980, 35b, 102.

19. Denizot, F.; Lang, R. J. Immunol. Methods 1986, 89, 271.

20. Decker, T.; Lohmann-Mathess, M. L.; Gifford, G. E. J. Immunol. 1987, 138, 957. 